Uluslararasi Hematoloji-Onkoloji Dergisi $\quad$ ReView International Journal of Hematology and Oncology

\title{
Occupation and Cancer
}

\author{
Tevfik PINAR \\ Kirikkale University Faculty of Medicine, Kirikkale, TURKEY
}

\begin{abstract}
Occupational cancer is malignant neoplasm caused by exposures to carcinogenic agents at workplace. It is estimated that one out of every three people will subsequently develop cancer during their lifetime in industrialized countries. Undeveloped countries are also at increasing risk due to transfer of hazardous industries. An occupational cancer does not differ either pathologically or clinically from their counterparts, and treated with the same approaches as similar cancers that are not related to occupational exposures. Whereas, the identification of occupational cancers in public health terms is very important, because all occupational cancers are preventable like other occupational diseases. Physicians generally underestimate the questioning of occupational history of their patients. However, a complete and detailed query of their occupations, and the determination of agents, which they exposed in workplace simply provide us earlier diagnosis, even prevention of occupational cancers. In occupational settings, the most successful measure for the prevention of occupational cancer is the complete removal of known or suspected carcinogenic agents from the workplace. Substitution, changing production process, industrial hygiene practices and education of employees may reduce exposure levels and prevent development of cancer. So that, occupational cancers can be successfully prevented without any harm to industry.
\end{abstract}

Keywords: Occupational cancer, Occupation, Prevention

ÖZET

\section{Meslek ve Kanser}

Mesleki karser, işyerinde karsinojenik etkene maruziyet sonucu oluşan malign neoplazmdır. Endüstrileşmiş ülkelerde her üç kişiden birinde yaşamları boyunca kanser görülebileceği tahmin edilmektedir. Mesleki kanserlerin patolojileri ya da klinikleri mesleki maruziyete bağı olmadan gelişen kanserlerden farkı değildir ve aynı şekilde tedavi edilirler. Ancak, mesleki kanserlerin tanısı halk sağı̆̆ı açısından çok önemlidir, çünkü bütün mesleki kanserler, diğer bütün mesleki hastallılarda olduğu gibi, önlenebilirdir. Hekimler genellekle hastalarının mesleklerini sormayı ihmal ederler. Oysa, tam ve detaylı bir meslek anamnezi ve işyerinde maruz kalınan etkenlerin belirlenmesi, bize mesleki kanserin kolaylıkla erken tanısı hatta önlenmesi imkanını sağlar. Mesleki kanserlerin önlenmesinde en başarılı önlem, bilinen ya da şüphelenilen karsinojenin işyerinden tamamen uzaklaştııımasıdır. Ikame (Zararı maddenin yerine daha az zararlı olanın kullanılması), üretim prosesinin değiştirilmesi, endüstriyel hijyen uygulamaları ve çalışanların eğitimi maruziyet düzeyini azaltabilir ve kanser gelişimini önleyebilir. Böylece, endüstriye zarar vermeden mesleki kanserler önlenebilir.

Anahtar Kelimeler: Mesleki kanser, Meslek, Önleme 


\section{INTRODUCTION}

The cancer is a multifactoral disease resulting from genetic, environmental exposure, and lifestyle factors. Occupational cancer is malignant neoplasm caused by exposures to carcinogenic agents at the workplace. ${ }^{1}$ Many workers are unaware of those potential hazards in their workplace, which makes them more vulnerable to cancer. Nearly 5-15\% of cancers are attributed to occupational exposures, but for bladder cancer this value may reach as high as $20 \% .^{1-5}$ In industry, there are many potential exposures to carcinogens that can cause cancer. It is estimated that one out of every three people will subsequently develop cancer during their lifetime in industrialized countries. ${ }^{2,5.6}$ Although 885 chemicals are estimated to be possible carcinogenic agents, only 22 chemicals among them are group I (carcinogenic to humans) carcinogenic agents. ${ }^{5}$

The first occupational cancer was reported in 1775 by Percival Pott describing scrotal cancer in children climbing up narrow chimneys that were stil hot and sweeping them..$^{1-3,7}$ Pott clearly identified soot as the cause of scrotal cancer in London chimney-sweeps. But, an experimental model for soot carcinogenesis was established almost 150 years after the original epidemiological data of Pott. ${ }^{8}$ It was not until the 1940s that a PAH, benzo[a]pyrene, have ability to induce skin cancers in laboratory animals, and it is an ingredient of soot. ${ }^{3,9}$

An occupational cancer does not differ either pathologically or clinically from their counterparts, and treated with the same approaches as similar cancers that are not related to occupational exposures. ${ }^{1.5}$ The identification of occupational cancers in public health terms is very important, because all occupational cancers are preventable like other occupational diseases with appropriate industrial hygiene practices and legislations. . $3,5,10^{2}$

\section{MECHANISMS OF CARCINOGENESIS}

Carcinogenesis is considered to have at least three stages: initiation, promotion and progression. Initiation is an irreversible mutation in the DNA caused by an interaction with a carcinogenic agent. This mutation is necessary, but not sufficient, for the development of cancer. Several occupational agents are associated with p53 mutations such as ultraviolet light, vinyl chloride, and asbestos. ${ }^{13,11}$ Promotion (epigenetic mechanism) consist of particular processes facilitating cancer development. In this phase, mutated cells are stimulated for proliferation. ${ }^{3}$ Progression is the development of malignant neoplasms from benign tumors. ${ }^{1,11}$

Occupational carcinogenic agents may increase the risk of cancer development at the stage of initiation by causing mutations in DNA or at the promotion phase by various "epigenetic" mechanisms, which do not involve DNA damage, including increased cell proliferation. Almost all occupational carcinogens are demonstrated to be mutagenic agents, and therefore occupational cancers appear to be started at the stage of initiation, and multiple mutations are required for the development of cancer. This explains the long "latency" period of occupational cancers. Besides, further required mutations may never occur after occupational exposures, and cancer may never develop. On the other hand, some occupational exposures such as benzene, arsenic, phenoxy herbicides are not mutagens, but seems to act as promoting agents. Therefore latency period may be shorter than the initiating occupational carcinogenic agents. ${ }^{1.2,5}$

Occupational cancers have a long latency period that is not less than 10-15 years and may be much longer such as 40-50 years observed in the case of asbestos-related cancers. Therefore, the presentation of some occupational cancers may appear in the retirement period. ${ }^{1,5}$

\section{DIAGNOSIS OF OCCUPATIONAL CANCERS}

The characteristics of occupational carcinogenic agent and the long latency period make the recognition of occupational carcinogens very difficult and lead to uncertainty over which occupational exposures cause cancer., ${ }^{2,3}$ A worker may be exposed to many different carcinogens in workplace, and he could not remember the causative agent, since exposure may be long past. Therefore it is difficult to find the responsible agent, and population-based epidemiological approaches may be required..$^{5}$

There are some characteristics that may help us to differentiate occupational cancers related to work. 
For instance, some occupational cancer for a group of workers may be observed by an obvious excess of cancers than normally expected in general population. Workers may talk about many cancer cases at work. ${ }^{1}$ It is easier to detect association of occupational cancer with exposure in case of unusual cancers. ${ }^{5}$ Those types of uncommon cancers called 'Signal Tumors' are related with specific occupation such as a liver angiosarcoma may be an indicative of past exposure history to vinyl chloride monomer. ${ }^{1}$ However, occupational cancers are frequently observed in more common histological types. Therefore, those type of more common cancers, such as squamous cell carcinoma of lung, are very difficult to identify since they may be due to asbestos, arsenic, nickel. ${ }^{5}$ A younger age at presentation with cancer may suggest an occupational cancer particularly for tumors commonly observed in later stages of life such as urothelial tract cancers under 50 years. ${ }^{1}$

\section{OCCUPATIONAL CARCINOGENIC AGENTS}

Specific scientific methodologies are used for the detection of occupational causes of cancer: (1) epidemiological studies, (2) animal studies, and (3) laboratory studies performed on the biological features of the agents. ${ }^{5}$

The International Agency for Research on Cancer (IARC) is a scientific agency to identify and evaluate carcinogenic hazards of physical, chemical or biolological agents to humans. In the monographs of IARC, some 885 agents have been evaluated..$^{1,2,5}$ However, only 22 agents are found to be occupational carcinogenic agents. Table 1-2 shows occupational exposures known or strongly suspected to cause cancer in humans.

Some important agents have not been assessed by IARC such as ionizing radiation and electromagnetic fields. Our current knowledge of occupational exposures and cancer relationship is not complete, and no clear evidence exist on exposed workers for many experimental carcinogenic agents. On the other hand, we have extensive evidences of increased cancer risk in particular industries and occupations, although we have no specific etiological agents. ${ }^{2}$

\section{OCCUPATIONAL CANCERS}

\section{LUNG CANCER}

The major cause of lung cancer is cigarette smoking. Lung cancer due to occupational exposures ranges from $3-40 \%$. However, it is very difficult to differantiate occupational causes from lung cancer associated with smoking and several types of lung cancer are the combination of occupational factors and smoking. Furthermore, the long latency period makes the determination of casual relationship even more difficult. Nevertheless, both non-occupational and occupational lung cancer is a preventable disease. ${ }^{11}$ The exposure to asbestos, radon, chloromethyl ethers, PAHs, nickel chromium, and inorganic arsenic are all independent risk factors from smoking for the development of lung cancer. However, smoking synergistically enhanced the effects of those occupational carcinogens such as asbestos..$^{3,5,12}$

\section{MESOTHELIOMA}

Mesotheliomas are classiscal example of "signal tumors". Because almost all cases of malignant mesothelioma are related to asbestos or erionite exposure. Mesothelioma has a long latency, generally 20 to 60 years from the first asbestosis exposure. . $^{3,11,13,14}$

\section{NONMELANOMATOUS SKIN CANCERS}

The primary causes of skin cancer in industry are ultraviolet radiation (solar), PAHs, arsenic, and ionizing radiation. Unna in 1890 reported changes in the skin of sailors, and shown increased skin cancers due to prolonged exposure to the sun. .,3, $^{2,15-18}$ Percival Pott shown the increased incidence of scrotal cancer in chimney sweeps in 1775, and PAHs, which was demonstrated to be the real cause of scrotal cancer later in 1940s. Skin cancers may also related with arsenic ingestion, inhalation and from skin contact. ${ }^{3,9}$ Ionizing radiation ,currently, is not responsible for skin cancers due to strict industrial controls and occupational legislations. .,3,9,15 $^{2}$

\section{BLADDER CANCER}

It is estimated that one fifth of all bladder cancers may result from occupational exposures. Rehn 


\begin{tabular}{|c|c|c|}
\hline Exposure & Human target organ(s) & Main industry/use \\
\hline 4-aminobiphenyl & Bladder & Rubber manufacture \\
\hline Arsenic and arsenic compounds ${ }^{\star \star}$ & Lung, skin & Glass, metals, pesticides \\
\hline Asbestos & Lung, pleura, peritoneum & Insulation, filter material, textiles \\
\hline Benzene & Leukemia & Solvent, fuel \\
\hline Benzidine & Bladder & Dye/pigment manufacture, laboratory agent \\
\hline Beryllium & Lung & Aerospace industry/metals \\
\hline Bis(chloromethyl)ether & Lung & Chemical intermediate/ by-product \\
\hline Chloromethyl methyl ether (technical grade) & Lung & Chemical intermediate/by-product \\
\hline Cadmium and cadmium compounds & Lung & Dye/pigment manufacture \\
\hline Chromium compounds & Nasal cavity, lung & Metal plating, dye/pigment manufacture \\
\hline Coal-tar pitches & Skin, lung, bladder & Building material, electrodes \\
\hline Coal-tars & Skin, lung & Fuel \\
\hline Ethylene oxide & Leukemia & Chemical intermediate, sterilant \\
\hline Mineral oils, untreated and mildly treated & Skin & Lubricant \\
\hline Mustard gas (sulphur Mustard) & Pharynx, lung & War gas \\
\hline 2-naphtylamine & Bladder & Dye/pigmet manufacture \\
\hline Nickel compounds & Nasal cavity, lung & Metallurgy, alloys, catalyst \\
\hline Shale-oils & Skin & Lubricants, fuels \\
\hline Soots & Skin, lung & Pigments \\
\hline Talc containing asbestiform fibers & Lung & Paper, paints \\
\hline Vinyl chloride & Liver, lung, blood vessels & Plastics, monomer \\
\hline Wood dust & Nasal cavity & Wood industry \\
\hline
\end{tabular}

described a high incidence of bladder cancers among aniline dye workers in 1895 . The first occupational bladder cancers in the United States were reported among workers exposed to ß-naphthylamine or benzidine and alpha-naphthylamine in 1934. The incidence of bladder cancer is the highest in industrialized countries, and the incidence in less developed countries is about $70 \%$ lower than in the United States. . $3,11,1,19,20^{2}$

A substantial evidence exist for an increased risk of bladder cancer among plumbing, tobacco, metal, heating and air conditioning workers. ${ }^{11,21-23}$ The latency period between exposure and bladder cancer was estimated to be about 20 years. ${ }^{3}$

\section{BRAIN CANCER}

Occupationally-related brain cancer is not clearly reported. However, ionizing radiation is a strong risk factor for brain cancer. Some reports shown that brain cancer may increase among workers exposed to polyvinyl chloride (PVC), and electrical, electronics, and petrochemical workers. ${ }^{2,11,24-28}$ 


\begin{tabular}{|c|c|c|}
\hline Exposure* $^{*}$ & Human target organ(s) & Main industry/use \\
\hline Acrylonitrile & Lung, prostate, lymphoma & Plastics, rubber, textiles, monomer \\
\hline Benzidine-based dyes & - & Paper, leather, textile dyes \\
\hline 1,3-Butadine & Leukemia, lymphdma & Plastics, rubber, monomer \\
\hline $\begin{array}{l}p \text {-Chloro-o-toluidine } \\
\text { and its strong acid salts }\end{array}$ & Bladder & $\begin{array}{l}\text { Dye/pigment manufacture, } \\
\text { textiles }\end{array}$ \\
\hline Creosotes & Skin & Wood preservation \\
\hline Diethyl sulphate & - & Chemical intermediate \\
\hline Dimethylcarbamoyl Chloride & - & Chemical intermediate \\
\hline Dimethyl sulphate & - & Chemical intermediate \\
\hline Epichlorohydrin & - & Plastics/resin monomer \\
\hline Ethylene dibromide & - & Chemical intermediate, fumigant, fuels \\
\hline Formaldehyde & Nasopharynx & Plastics, textiles, laboratory agent \\
\hline $\begin{array}{l}\text { 4,4'-Methylene-bis- } \\
\text { 2-chloroaniline (MOCA) }\end{array}$ & Bladder & Rubber manufacture \\
\hline Polychlorinated biphenyls & Liver, bile ducts,Leukemia, lymphoma & Electrical components \\
\hline Silica & Lung & Stone cutting, mining, glass, paper \\
\hline Styrene oxide & - & Plastics, chemical intermediate \\
\hline Tetrachloroethylene & Oesophagus, lymphoma & Solvent, dry cleaning \\
\hline Trichloroethylene & Liver, lymphoma & Solvent, dry cleaning, metal \\
\hline Tris(2,3-dibromopropyl) phosphate & - & Plastics, textiles, flame retardant \\
\hline Vinyl bromide & - & Plastics, textiles, monomer \\
\hline Vinyl fluoride & - & Chemical intermediate \\
\hline
\end{tabular}

\section{THYROID CANCER}

Ionizing radiation is a well-documented cause of thyroid cancer. Epidemiological studies of Atomic Bombing to Hiroshima and Nagasaki, Chernobyl nuclear reactor incident, and Marshall Islands following aboveground detonation of an atomic bomb in 1954 clearly showed that ionizing radiation increase the risk of thyroid cancer. ${ }^{11}$

\section{SINONASAL CARCINOMAS}

Several occupational exposures are related to sinonasal carcinomas. Especially, some studies clearly showed that wood dust increase the risk of sinonasal cancer $15-45$ fold. ${ }^{29,30}$ Sinonasal cancers have been also shown in female workers exposed to radium used for painting dials of watches and in radon chemists. ${ }^{3}$ Furthermore, exposure to nickel compounds in refining processes, and hexavalent chromium in pigment manufacturing may also increase the risk of sinonasal cancer.."

\section{LARYNGEAL CANCER}

Asbestos exposure in miners, shipyard workers, asbestos product manufacturers, and insulators has been shown to increase laryngeal cancer incidence. ${ }^{3,31-34}$ Occupational exposure to solvents was associated with an increased risk of hypopharyngeal/laryngeal cancer. ${ }^{32-34}$ 


\section{ESOPHAGEAL CANCER}

Some studies showed that the risk of esophageal cancer is high in workers exposed to tetrachloroethylene, mustard gas, silica dust, asbestos, combustion products, sulphuric acid, and ionizing radiation. ${ }^{2,11,35}$ Workers in metal-grinding operations, metal polishers and platers, and drycleaners have been reported to be at increased risk of esophageal cancer. ${ }^{11}$

\section{HEPATIC ANGIOSARCOMA}

Liver angiosarcoma has a strong causal relationship with vinyl chloride and arsenic exposure such as arsenical pesticides, arsenic-contaminated wine. . $^{2,11,27,36-38}$

\section{KIDNEY CANCER}

Several studies reported that kidney cancer is associated with exposure to chlorinated aliphatic hydrocarbons. ${ }^{2,11,39}$ Increased risk of renal cell cancer has been shown for dry-cleaning workers, painters, iron and steel industry workers, coke oven workers, firefighters, asbestos-exposed workers, textile workers, gasoline station attendants, nickel-smelting workers, lead-smelter workers, oil refinery workers, truck drivers, electric power utility workers, farmers, and printers. ${ }^{11,40}$

\section{PANCREATIC CANCER}

Occupational exposures to nickel, chlorinated hydrocarbon solvents, chromium, polycyclic aromatic hydrocarbons (PAHs), organochlorine insecticides, silica dust, and aliphatic and aromatic hydrocarbons may cause pancreatic cancer., ${ }^{2,11,41,42}$ An elevated pancreatic cancer risk among dry cleaners and among workers exposed to cadmium was demonstrated in independent meta-analyses. Elevated pancreatic cancer mortality was also shown in cohort studies among workers processing vinyl resins and polyethylene, producing chlorohydrin with potential exposure to ethylene dichloride and bis-chloroethyl ether (BCEE), and manufacturing DDT, leather tannery workers. ${ }^{11,43}$

\section{COLORECTAL CANCER}

Increased colon cancer has been reported among workers exposed to mineral oils used in printing, cellulose acetate fiber and polypropylene and textiles are at increased risk of colorectal cancer. ${ }^{2,11,44}$ Some studies shown that higher incidence among the most sedentary compared to the most active occupations. ${ }^{2,45,46}$

\section{SOFT TISSUE SARCOMA}

Liver angiosarcoma is considered as a "signal" cancer of occupational etiology. Vinyl chloride is a well-known cause of liver angiosarcoma. Ionizing radiation is an established cause of soft tissue sarcomas. Dioxin has been shown to be associated with occupational soft tissue sarcomas. . $^{211,47}$

\section{HEMATOLOGIC CANCERS}

\section{LEUKEMIA}

Acute nonlymphocytic leukemia (ANLL) and chronic myelogenous leukemia (CML) have been linked to occupational exposure, and CML has been called an industrial disease. Radiation is the most conclusively known leukemogenic factor in human. Maximal risk occurs 4-7 years after exposure to ionizing radiation. Workers at risk secondary to exposure to ionizing radiation include radiologists, radiation therapists, nuclear medicine physicians and radiation technicians working with $\mathrm{X}$-rays in the medical workplace, workers in nuclear power plants, military personnel working in nuclear tests, and uranium miners..$^{3,48,49}$

Epidemiologic studies have demonstrated significant increase in leukemia incidence in workers with past exposure to benzene..$^{2,3,11,50}$ It has been shown that there is a 21 -fold increased death risk from leukemia in workers exposed to benzene for 5 years or more. Ethylene oxide organic hydrocarbons exposure has been associated with an increased risk of leukemia. The increased risk of leukemia after exposure to electromagnetic fields is unclear..$^{3,11,51,52}$

\section{LYMPHOMA}

Several reports shown that chemical industry workers and farmers in Scandinavia, Europe, North America, Australia, and New Zealand are at risk for non-Hodgkin's lymphoma. Some studies reported that paper workers, chemists, rubber workers, and firefighters are at increased risks of lymphoma. 
Some chemicals such as phenoxyacetic acid herbicides, dioxins, and benzene have been suggested as causative agents for lymphoma. ${ }^{2,11,53-55}$

\section{MULTIPL MYELOMA}

An association between multiple myeloma and ionizing radiation exposure has been observed in the survivors of the atomic bombings of Hiroshima and Nagasaki. Some epidemiologic studies suggest an association of exposure to dioxin, benzene and multiple myeloma. Exposure to petroleum products, heavy metals, pesticides, diesel-engine exhaust and asbestos is concerned, but those studies are small, and not conclusive. ${ }^{2,3,56,57}$

\section{DISCUSSION}

High labor costs and strict legislations in industrialized countries cause the transfer of hazardous industries to the developing countries due to insecure status of workers, the lack of legislative protection, low wages and unemployment in those regions. ${ }^{2.58 .59}$ Therefore, the incidence of occupational cancer has not been reduced worldwide, since occupational exposures have been transferred to the developing world. The industrial activity is fragmented in the form of small industries in developing world, and these small production facilities have been using old machineries in unsafe buildings. Employers in those places cannot even provide safe environmental workplace conditions and precautions such as personal safety equipments due to their limited financial resources. Furthermore, workers have poor training and education in those facilities. These small enterprises are generally scattered, and health and safety enforcement agencies have difficulties to inspect those facilities. ${ }^{2}$

Primary prevention is to prevent the onset of a disease. It is the most important and easiest way to deal with any kind of disease including malignant disorders. In occupational settings, the most successful measure for the prevention of occupational cancer is the complete removal of known or suspected carcinogenic agents from the workplace. ${ }^{2,60}$ However, the determination of causative relationship between cancer and carcinogenic agent requires a long latency period. In several instances, industrialized countries missed their chance to pre- vent occupational cancers. However, those experiences may be a great chance for developing countries to take earlier precautions for preventing occupational cancers. ${ }^{2,61}$

Substitution, in many cases, is another major method for prevention, since complete removal of a carcinogenic agent is mostly not possible due to economical or political judgements. ${ }^{2.59}$ In this manner, changing production process as well as industrial hygiene practices may alternatively reduce exposure levels. Education of employers, employees and managers is also an essential steps for prevention. Risk based legislations and social policies support these training approaches..1

Physicians generally underestimate the questioning of occupational history of their patients. However, a complete and detailed query of their occupations, and the determination of agents, which they exposed in workplace simply provide us earlier diagnosis, even prevention of occupational cancers. Furthermore, the awareness of occupational physicians about the industrial cancer risks at preemployment or periodical examinations is also crucial in the prevention of occupational cancers. ${ }^{62}$

In conclusion, the occupational cancer prevention measurements in industrialized world has shown us that occupational cancers can be successfully prevented without leading our industry to collapse, and several different approaches is highly possible by using the experiences of developed countries if satisfactory legislations and control of occupational carcinogenic agents are provided.

\section{REFERENCES}

1. Hobson J. Occupational cancers. In: ABC of Occupational and Environmental Medicine, Edited by David Snashall and Dipti Patel. Second edition. London BMJ, 2003: 86-93.

2. Encyclopedia of occupational health and safety, Editor: Jeanne Mager Stellman. Fourth Edition. Geneva, International Labour Office, 1998: Volum I, 2.1-2.8.

3. Joseph Ladou LANGE-Current Occupational and Environmental Medicine. Fourth edition. New York, McGrawHill, 2007: 224-333.

4. Vineis $P$, Simonato L. Proportion of lung and bladder cancer in males resulting from occupation: A systemic approach. Arch Environ Health 46: 6-15, 1991.

5. Tee L. Guidotti. Global Occupational Health. New York, Oxford University Press, 2011: 317-328. 
6. Kogevinas M, Boffetta P, Pearce N. Occupational exposure to carcinogens in developing countries. In: Occupational Cancer in Developing Countries, edited by Pearce NE, Matos E, Vainio H, Boffetta P, Kogevinas M. Lyon: International Agency for Research on Cancer (IARC), 1994: 63-96.

7. Checkoway H, Pearce NE, Crawford-Brown DJ. Research Methods in Occupational Epidemiology. New York, Oxford University Press., 1989

8. Decoufle P. Occupation. In: Cancer Epidemiology and Prevention. Edited by D Schottenfeld and JF Fraumenti. Philadelphia, WB Saunders, 1982.

9. Gawkrodger DJ. Occupational skin cancers. Occup Med (Lond). 54: 458-463, 2004.

10. Pearce NE, Matos E. Strategies for prevention of occupational cancer in developing countries. In: Occupational Cancer in Developing Countries, edited by Pearce NE, Matos E, Vainio H, Boffetta P, Kogevinas M. Lyon: International Agency for Research on Cancer (IARC), 1994: 173-184.

11. Ennever FK. Biologically based mathematical models of lung cancer risk. Epidemiology 4: 193-194, 1993.

12. Grimsrud TK, Berge SR, Martinsen JI, Andersen A. Lung cancer incidence among Norwegian nickel-refinery workers 1953-2000. J Environ Monitor 5: 190197, 2003.

13. Hemminki $\mathrm{K}, \mathrm{X}$ Li. Time trends and occupational risk factors for pleural mesothelioma in Sweden. J Occup Environ Med, 2003. 45: 456-461, 2003.

14. Bang KM, Pinheiro GA, Wood JM, Syamlal G. Malignant mesothelioma mortality in the United States, 1999-2001. Int J Occup Environ Health 12: 9-15, 2006.

15. Ramirez CC. Skin cancer as an occupational disease: The effect of ultraviolet and other forms of radiation. Int Dermatol 44: 95, 2005.

16. Suarez B, Lopez-Abente G, Martinez C, et al. Occupation and skin cancer: the results of the HELIOS-I multicenter case-control study. BMC Public Health 7: 180, 2007.

17. Yoshinaga S, Hauptmann M, Sigurdson AJ, et al. Nonmelanoma skin cancer in relation to ionizing radiation exposure among U.S. radiologic technologists. Int J Cancer. 115: 828-834, 2005.

18. Vishvakarman D, Wong JCF. Description of the use of a risk estimation model to assess the increased risk of non-melanoma skin cancer among outdoor workers in Central Queensland, Australia. Photodermatol Photoimmunol Photomed 19: 81-88, 2003.

19. Liu CS. Occupational bladder cancer in a 4,4'-methylene bis(2- chloroaniline) (MBOCA)-exposed worker. Environ Health Perspect 113: 771-774, 2005.

20. Talaska G. Aromatic amines and human urinary bladder cancer: Exposure sources and epidemiology. J Environ Sci Health C Environ Carcinog Ecotoxicol Rev 21: 29-43, 2003.

21. Gaertner RR, Trpeski L, Johnson KC. A case-control study of occupational risk factors for bladder cancer in Canada. Cancer Causes Control 15: 1007-1019, 2004.
22. Yaris F, Dikici MF, Sabuncu HH, Yaris E. A case-control study on the etiology of urinary bladder cancer in Istanbul, Turkey. Asian Pac J Cancer Prev 7: 591-594, 2006.

23. Ugnat AM, Luo W, Semenciw R, Mao Y. Occupational exposure to chemical and petrochemical industries and bladder cancer risk in four western Canadian provinces. Chronic Dis Can 25: 7-15, 2004.

24. Van Wijngaarden E, Steward PA, Olshan AF, et al. Parental occupational exposure to pesticides and childhood brain cancer. Am J Epidemiol 157: 989997, 2003.

25. Buffler PA, Kelsh MA, Kalmes RM, et al. A Nested Case-Control Study of Brain Tumors Among Employees at a Petroleum Exploration and Extraction Research Facility. J Occup Environ Med 49: 791-802, 2007.

26. Buffler PA, Kelsh M, Chapman P, et al. Primary brain tumor mortality at a petroleum exploration and extraction research facility. J Occup Environ Med 46: 25770, 2004.

27. Lewis R, Rempala G. A case-cohort study of angiosarcoma of the liver and brain cancer at a polymer production plant. J Occup Environ Med 45: 538-545, 2003.

28. Zheng $\mathrm{T}$, Cantor $\mathrm{KP}$, Zhang $\mathrm{Y}$, et al. Occupational risk factors for brain cancer: A population-based casecontrol study in lowa. J Occup Environ Med 43: 317 324, 2001.

29. Demers PA, Kogevinas M, Boffetta P, et al. Wood dust and sino-nasal cancer: Pooled reanalysis of twelve case-control studies. Am J Ind Med 28: 151-166, 1995.

30. Luc D, Leclerc A, Begin D, et al. Sinonasal cancer and occupational exposures: A pooled analysis of 12 casecontrol studies Cancer Causes and control 13: 147157, 2002.

31. Pinar T, Akdur R, Tuncbilek A, Altundag $\mathrm{K}$, et al. The Relationship Between Occupations and Head and Neck Cancers. Journal of the National Medical Association 99: 1-5, 2007.

32. Berrino F, Richiardi L, Boffetta P, et al. Occupation and larynx and hypopharynx cancer: a job-exposure matrix approach in an international case-control study in France, Italy, Spain and Switzerland. Cancer Causes Control 14: 213-223, 2003.

33. Boffetta P, Richiardi L, Berrino F, et al. Occupation and larynx and hypopharynx cancer: An international casecontrol study in France, Italy, Spain, and Switzerland. Cancer Causes and Control 14: 203-212, 2003.

34. Sato H, Murai K, Kanda T, et al. Association of chromium exposure with multiple primary cancers in the nasal cavity. Auris Nasus Larynx 30: 93-96, 2003.

35. Parent M, Siemiatycki J, Fritsch L. Workplace exposures and oesophageal cancer. Occup Environ Med 57: 325-334, 2000.

36. Creech JL, Johnson MN. Angiosarcoma of liver in the manufacture of pdlyvinyl chloride. J Occup Med 16: 150-151, 1974. 
37. Falk H, Caldwell GG, Ishak KG, et al. Arsenic-related hepatic angiosarcoma. Am J Indust Med 2: 43-50, 1981.

38. Encyclopedia of occupational health and safety, Fourth Edition. Editor: Jeanne Mager Stellman. International Labour Office, Geneva, 1998: Volum I, 2.14.9.

39. Schulte PA, Ringen K, Hemsteet GP, et al. Occupational cancer of the urinary tract. Occup Med 2: 87-93, 1987.

40. Ji J, Granstrom C, Hemminki K. Occupational risk factors for kidney cancer: a cohort study in Sweden. World J Urol 23: 271-278, 2005.

41. Ojajarvi IA, Partanen TJ, Ahlbom A, et al. Occupational exposures and pancreatic cancer: a meta-analysis. Occupat Environ Med 57: 316-324, 2000.

42. Siemiatycki J, Gerin M, Dewar L, et al. Association between occupational circumstances and cancer. In: Risk Factors for Cancer in the Workplace, edited by $\mathrm{J}$ Siemiatycki. Boca Raton: CRP Press, 1991.

43. Alguacil J, Porta M, Kauppinen T, et al. Occupational exposure to dyes, metals, polycyclic aromatic hydrocarbons and other agents and K-ras activation in human exocrine pancreatic cancer. Int J Cancer 107: 635-641, 2003.

44. Goldberg MS, Parent ME, Siemiatycki J, et al. A casecontrol study of the relationship between the risk of colon cancer in men and exposures tı occupational agents. Am J Indust Med 39: 531-546, 2001.

45. Longnecker MP, Gerhardsson le Verdier M, Frumkin $\mathrm{H}$, et al. A case-control study of physical activity in relation to risk of cancer of the right colon and rectum in men. Int J Epi 24: 42-50, 1995.

46. Fredriksson M, Bengtsson NO, Hardell L, Axelson O. Colon cancer, physical activity, and occupational exposures. A case-control study. Cancer 63: 18381842, 1989.

47. Zahm SH, Fraumeni JF Jr. The epidemiology of soft tissue sarcoma. Seminars in Oncol 24: 504-514, 1997.

48. Mohner M, Lindtner M, Otten H, Gille HG. Leukemia and exposure to ionizing radiation among German uranium miners. Am J Ind Med 49: 238-428, 2006.

49. Feychting M, Forssén U, Floderus B. Occupational and residential magnetic field exposure and leukemia and central nervous system tumors. Epidemiol 8: 384389, 1997.

50. Hayes RB, Songnian Y, Dosemeci M, et al. Benzene and lymphohematopoietic malignancies in humans. Am J Indust Med 40: 117-126, 2001.

51. Costantini AS, Quinn M, Consonni D, Zappa M. Exposure to benzene and risk of leukemia among shoe factory workers. Scandinavian J Work, Environ Health 29: 51-59, 2003.

52. Aksoy M. Malignancies due to occupational exposure to humans. Am J Ind Med 7: 395-402, 1985.

53. Zheng $\mathrm{T}$, Blair $\mathrm{A}$, Zhang $\mathrm{Y}$, et al. Occupation and risk of non-Hodgkin's lymphoma and chronic lymphocytic leukemia. J Occup Environ Med 44: 469-474, 2002.
54. Vajdic CM, Fritschi L, Grulich AE, et al. Atopy, exposure to pesticides and risk of non-Hodgkin lymphoma. Int J Cancer 120: 2271-2274, 2007.

55. Mester B, Nieters A, Deeg E, et al. Occupation and malignant lymphoma: a population based case control study in Germany. Occup Environ Med 63: 17-26, 2006.

56. Cardis E, Gillbert ES, Carpenter L, et al. Effects of low doses and low dose rates of external ionizing radiatio: Cancer mortality among nuclear workers in three countries. Radiat Res 142: 117-132, 1995.

57. Eriksson M, Karlsson M. Occupational and other environmental factors and multiple myeloma: a population based case-control study. $\mathrm{Br} J$ Indust Med 49: 95103, 1992.

58. Jeyaratnam J. Transfer of hazardous industries. In: Occupational Cancer in Developing Countries, edited by Pearce NE, Matos E, Vainio H, Boffetta P, Kogevinas M. Lyon: International Agency for Research on Cancer (IARC). Lyon, International Labour Office, 1994: 23-30

59. Pearce NE, Matos E, Koivusalo M, Wing S. Industrialisation and Health. In: Occupational Cancer in Developing Countries, edited by Pearce NE, Matos E, Vainio H, Boffetta P, Kogevinas M. Lyon: International Agency for Research on Cancer (IARC). Lyon, International Labour Office, 1994: 7-22.

60. Anon A. Bladdet tumours in industry. Lancet 2: 1173, 1965.

61. Swerdlow AJ. Effectiviness of primary prevention of occupational exposures on cancer risk. In: Evaluating Effectiveness of Primary Prevention of Cancer, edited by Hakam M, Veral V, Cullen JW, Parkin DM. IARC Scientific Publications, No.103. Lyon: International Agency for Research on Cancer (IARC), 1990.

62. Pınar T, Cakmak ZA, Saygun M, Ulu N. Hasta Dosyalarında Tanı ve Tedaviyi Etkileyebilecek Meslek ve Diğer Faktörlerin Tibbi Kayitlarda Yer Alma Durumlarının Değerlendirilmesi. Türkiye Klinikleri J Med Sci 28: 40-47, 2008.

\section{Correspondence}

Dr. Tevfik PINAR

Kırıkkale Üniversitesi Tıp Fakültesi

Halk Sağlığı Anabilim Dalı

Kırıkkale / TURKEY

Tel-Fax: (+90.312) 4958983

e-mail: tevfikpinar@gmail.com 